\title{
A concise and simple synthesis of 1-hydroxy-phenethylamine derivatives: Formal synthesis of naturally occurring norephedrine, virolin and 3-hydroxy-2-phosphonylmethoxypropyl adenine
}

\author{
S SAHA $^{\mathrm{a}, \mathrm{b}}$, P CHAKRABORTY ${ }^{\mathrm{a}}$ and S C ROY ${ }^{\mathrm{a}, *}$ \\ a Department of Organic Chemistry, Indian Association for the Cultivation of Science, Jadavpur, \\ Kolkata 700 032, India \\ ${ }^{b}$ Department of Chemistry, National Institute of Technology, Sikkim 739 139, India \\ e-mail: ocscr@iacs.res.in
}

MS received 25 November 2013; revised 2 January 2014; accepted 11 January 2014

\begin{abstract}
A concise and simple synthesis of 1-hydroxy-phenethylamine derivatives has been achieved following classical organic transformations using commercially available chiral pools. The said derivatives were explored for the synthesis of naturally occurring bio-active small molecules. Formal synthesis of norephedrine, virolin and 3-hydroxy-2-phosphonylmethoxypropyl adenine has been demonstrated.
\end{abstract}

Keywords. Synthesis; 1-hydroxy-phenethylamine derivatives; intermediates; bio-active; small molecules.

\section{Introduction}

It is well-documented in the literature ${ }^{1}$ that 1-hydroxyphenethylamine derivatives with a core structure (I) are good synthons for a wide range of biologically active naturally occurring small molecules.<smiles>[Y]CC([R2])C([R])O</smiles>

$\mathrm{X}=\mathrm{O}, \mathrm{N}$ and $\mathrm{Y}=\mathrm{OH}, \mathrm{H}$

$\mathrm{R}_{1}=$ aryl, $\mathrm{R}_{2}=$ aryl or alkyl

$\alpha$-Hydroxy- $\beta$-amino esters and the vicinal amino diols are major contributing class with such core structure. Both of these structural moieties are significant not only for their own biological activity but also being a part of complex natural products such as vancomycin, chloramphenicol, GE2270 thiopeptide family, and Ustiloxin. ${ }^{\text {a, }}{ }^{1 \mathrm{~d}}$ Similarly, norephedrine, norpseudoephedrin, and cathionone are well-known naturally occurring biologically active alkaloids which act as stimulants, entactogens, and hallucinogens. ${ }^{2 a}$ Moreover, said structural moiety is widely used as useful starting material for the preparation of chiral 2oxazoline, piperidines, aziridines, and imidazolines. ${ }^{2}$

\footnotetext{
*For correspondence
}

It is known ${ }^{2 c}$ that the production cost of chemically synthesized ephedrine was sixty percent lower with better quality compared to extracted naturally occurring ephedrine. So, a good synthetic procedure is always desirable, and that is reflected in several recent publications. ${ }^{2 c, 3}$ We were interested in designing a general synthetic strategy for the stereoselective synthesis of 1-hydroxy-phenethylamine derivatives using commercially available or easily accessible chiral pools involving simple classical organic transformations. Carbohydrates and amino acids are well-known wealth of naturally occurring chiral pools with proper stereochemical dimension. Resemblance in chirality between the target and stock starting material is the necessary condition for the chiron approach. ${ }^{4}$ Most of the reported synthesis of ephedrine and related compounds dealt with recemic products although only a few are stereoselective but suffer from lack of generality. ${ }^{3}$ We report here a mild and concise synthesis of optically active 1-hydroxy-phenethylamine derivatives, the advanced intermediates for the synthesis of bio-active natural products. Formal synthesis of norephedrine, virolin and 3-hydroxy-2-phosphonylmethoxypropyl adenine has been demonstrated.

\section{Experimental}

Melting points were determined in open capillary tubes and are uncorrected. ${ }^{1} \mathrm{HNMR}$ and ${ }^{13} \mathrm{C}$ NMR spectra were recorded in $\mathrm{CDCl}_{3} 300$ and $500 \mathrm{MHz}$ 
spectrometer using tetramethyl silane as the internal standard. IR spectra were recorded on FT IR-8300 instrument. Column chromatography was performed on silica gel (60-120 mesh) and preparative TLC was performed using pre-coated silica $60 \mathrm{~F} 254$ plates $(0.2 \mathrm{~mm})$. High-resolution mass spectra were obtained using a Qtof Micro YA263 instrument. GC was performed at $130^{\circ} \mathrm{C}$ using BP1 column on Perichrom PR 2100 machine. Diethyl ether and tetrahydrofuran were freshly distilled from sodium. Methylene chloride was freshly distilled over calcium hydride. Light petroleum of boiling range $60-80^{\circ} \mathrm{C}$ was used for chromatography.

$\mathrm{X}$-ray single crystal data were collected using $\operatorname{MoK} \alpha$ $(\lambda=0.7107 \AA)$ radiation on a SMART APEX II diffractometer equipped with CCD area detector. Data collection, data reduction, structure solution/refinement were carried out using the software package of SMART APEX. The structure was solved by direct method and refined in a routine manner. Non-hydrogen atoms were treated anisotropically. The hydrogen atoms were geometrically fixed. CCDC 862357 contains the supplementary crystallographic data for this paper. These data can be obtained free of charge via www.ccdc.cam.ac. uk/conts/retrieving.html (or from the Cambridge Crystallographic Data Centre, 12 Union Road, Cambridge CB2 1EZ, UK; fax: (+44) 1223-336-033; or deposit@ ccdc.cam.ac.uk).

\subsection{Synthesis of (S)-tert-butyl 4-(hydroxy(phenyl) methyl-2,2-dimethyloxazolidine-3-carboxylate (1a and $\left.1 a^{l}\right)$}

Freshlyprepared Grignard reagent at $0^{\circ} \mathrm{C}$ [prepared from bromobenzene $(3 \mathrm{~g}, 0.02 \mathrm{~mol})$ and $\mathrm{Mg}(550 \mathrm{mg}$, $0.02 \mathrm{~mol})$ in THF $(20 \mathrm{~mL})$ ] was added to the Garner's aldehyde A (4.8 g, $0.02 \mathrm{~mol})$ in THF $(30 \mathrm{~mL})$ over a period of $1 \mathrm{~h}$. The mixture was stirred for $3 \mathrm{~h}$ at room temperature. Saturated aqueous $\mathrm{NH}_{4} \mathrm{Cl}$ was added to the reaction mixture, extracted with diethyl ether $(3 \times 70 \mathrm{~mL})$. The combined organic layer was washed successively with water $(3 \times 10 \mathrm{~mL})$ and brine $(5 \mathrm{~mL})$, and finally dried $\left(\mathrm{Na}_{2} \mathrm{SO}_{4}\right)$. The solvent was evaporated under reduced pressure and the residue obtained was purified by column chromatography over silica gel to afford an inseparable mixture of alcohols $\mathbf{1 a}$ and $\mathbf{1 a}^{\mathbf{1}}$ $(4.5 \mathrm{~g}, 70 \%)$ in almost equal ratio $\left[\mathrm{GC}\left(\mathrm{R}_{\mathrm{t}}=6.12\right.\right.$ and $6.15 \mathrm{~min})]$.

2.1a IR (neat): 3300, 3009, 2980, 1691, 1448, 1396, 1367, $1170 \mathrm{~cm}^{-1} ;{ }^{1} \mathrm{H}$ NMR $\left(500 \mathrm{MHz}, \mathrm{CDCl}_{3}\right): \delta$ $1.09(\mathrm{~s}, 3 \mathrm{H}), 1.21(\mathrm{~s}, 3 \mathrm{H}), 1.27-1.46(\mathrm{~m}, 9 \mathrm{H}), 3.65-$ $3.99(\mathrm{~m}, 1 \mathrm{H}), 4.02-4.07(\mathrm{~m}, 1 \mathrm{H}), 4.17-4.22(\mathrm{~m}, 1 \mathrm{H})$,
4.74-4.75 (m, 1H), 7.24-7.35 (m, 5H) ${ }^{13} \mathrm{C}$ NMR $\left(125 \mathrm{MHz}, \mathrm{CDCl}_{3}\right): \delta 23.1,23.2,25.9,26.4,28.0,48.7$, 49.0, 62.9, 64.0, 74.4, 94.5, 125.9, 127.1, 127.9, 128.2, 141.2. HRMS: calcd for $\mathrm{C}_{17} \mathrm{H}_{25} \mathrm{NO}_{4} \mathrm{Na}[\mathrm{M}+\mathrm{Na}]^{+}$ 330.1681; found 330.1681. The ${ }^{1} \mathrm{H}$ NMR spectrum was very complicated due to mixture of rotamers of both the isomers and there was no distinguishable signal for identifying the ratio of the isomers.

\subsection{Synthesis of (S)-tert-butyl 4-(yl(phenyl) methanone-2,2-dimethyloxazolidine-3-carboxylate (2a)}

To a stirred solution of compound $1(3.0 \mathrm{~g}, 9.8 \mathrm{mmol})$ and an excess of molecular sieves $(4 \AA)$ in $\mathrm{CH}_{2} \mathrm{Cl}_{2}$ $(20 \mathrm{~mL})$, pyridinium chlorochromate (PCC) $(3.2 \mathrm{~g}$, $14.7 \mathrm{mmol}$ ) was added in one portion. The stirring was continued for another $30 \mathrm{~min}$ for the complete conversion (monitored by TLC). Diethyl ether $(40 \mathrm{~mL})$ was added to the reaction mixture and the solids were filtered off. The filtrate was successively washed with aqueous $10 \% \mathrm{HCl}(10 \mathrm{~mL})$, water $(10 \mathrm{~mL})$ and brine $(10 \mathrm{~mL})$, and finally dried over $\mathrm{Na}_{2} \mathrm{SO}_{4}$. The crude product was purified by column chromatography $(10 \%$ ethyl acetate in light petroleum) to afford the pure keto compound 2a (2.4 g, 80\%, mixture of two rotamers) as crystalline solid, $\left.\mathrm{mp} 102-105^{\circ} \mathrm{C}\right)$. IR (KBr): 2982, 2857, 1703, 1651, 1396, 1361, 1246, $1172 \mathrm{~cm}^{-1} ;{ }^{1} \mathrm{H}$ NMR $\left(500 \mathrm{MHz}, \mathrm{CDCl}_{3}\right): \delta 1.28-1.76(6 \mathrm{~s}, 15 \mathrm{H}, \mathrm{Boc}$, $\left.2 \times \mathrm{CH}_{3}\right), 3.92-3.96(\mathrm{~m}, 1 \mathrm{H}, \mathrm{OCH}), 4.28-4.33(\mathrm{~m}, 1 \mathrm{H}$, $\mathrm{OCH}), 5.36$ (dd, J = 3.5, $\left.7.5 \mathrm{~Hz}, \frac{1}{2} \mathrm{H}, \mathrm{NCH}\right), 5.46$ (dd, $\left.\mathrm{J}=2.5,7 \mathrm{~Hz}, \frac{1}{2} \mathrm{H} \mathrm{NCH}\right), 7.44-7.51(\mathrm{~m}, 2 \mathrm{H}), 7.55-$ $7.60(\mathrm{~m}, 1 \mathrm{H}), 7.90-7.93(\mathrm{~m}, 2 \mathrm{H}) ;{ }^{13} \mathrm{C}$ NMR $(125 \mathrm{MHz}$, $\left.\mathrm{CDCl}_{3}\right): \delta 24.8,25.5,26.0,28.3,28.5,61.8,62.0,65.8$, $66.2,80.4,80.9,95.7,95.4,128.3,128.5,128.9,129.0$, 133.5, 133.6, 135.3, 151.4, 152.2, 195.3, 196.0; HRMS: calcd for $\mathrm{C}_{17} \mathrm{H}_{23} \mathrm{NO}_{4} \mathrm{Na}[\mathrm{M}+\mathrm{Na}]^{+} 328.1525$; found 328.1527. The ${ }^{1} \mathrm{H}$ NMR spectrum was complex due to the rotamers of $\mathbf{2} \mathbf{a}$.

\subsection{Synthesis of (S)-tert-butyl 4-((S)-hydroxy(phenyl) methyl-2,2-dimethyloxazolidine-3-carboxylate (1a)}

A suspension of $\mathrm{LiAlH}_{4} \mathrm{LiAlH}_{4}(890 \mathrm{mg}, 23 \mathrm{mmol})$ in THF $(20 \mathrm{~mL})$ was added drop-wise to a stirred solution of the keto compound $\mathbf{2 a}(2.3 \mathrm{~g}, 7.8 \mathrm{mmol})$ in THF $(10 \mathrm{~mL})$ at $-78^{\circ} \mathrm{C}$ under $\mathrm{N}_{2}$. The reaction was further stirred for $30 \mathrm{~min}$ at that temperature followed by the addition of $1 \mathrm{~mL}$ of $\mathrm{MeOH}$ and the temperature was gradually increased to $0^{\circ} \mathrm{C}$. A saturated aqueous solution of sodium potassium tartrate $(10 \mathrm{~mL})$ and excess of diethyl ether $(50 \mathrm{~mL})$ was added. The stirring was continued until complete precipitation. The solids were 
filtered off and the filtrate was washed successively with dilute aqueous $10 \% \mathrm{HCl}(10 \mathrm{~mL})$, water $(10 \mathrm{~mL})$ and brine $(10 \mathrm{~mL})$, and finally dried over $\mathrm{Na}_{2} \mathrm{SO}_{4}$. The organic solvent was evaporated under reduced pressure and the residue obtained was purified by column chromatography ( $15 \%$ ethyl acetate in light petroleum) to afford the alcohol 1a (mixture of two rotamers) ( $2.1 \mathrm{~g}$, $90 \%$ ) as a viscous mass. $[\alpha]_{\mathrm{D}}^{24.0}=+13.7$ (c, 2.01 in $\mathrm{CHCl}_{3}$ ); IR (neat): 3444, 2978, 2879, 1699, 1670, 1456, 1395, 1367, $1255 \mathrm{~cm}^{-1}$; ${ }^{1} \mathrm{H}$ NMR $(500 \mathrm{MHz}$, $\left.\mathrm{CDCl}_{3}\right): \delta 1.41(\mathrm{~s}, 6 \mathrm{H}), 1.47(\mathrm{~s}, 9 \mathrm{H}), 3.60-3.61(\mathrm{~m}$, 1H), 3.68-3.69 (m, 1H), 4.05 (brs, 1H), 4.19-4.21 (m, $1 \mathrm{H}), 4.74(\mathrm{~d}, \mathrm{~J}=8.5 \mathrm{~Hz}, 1 \mathrm{H}), 7.19-7.31(\mathrm{~m}, 5 \mathrm{H})$; ${ }^{13} \mathrm{C}$ NMR $\left(125 \mathrm{MHz}, \mathrm{CDCl}_{3}\right): \delta 24.4,27.0,27.3,28.5$, 63.8, 64.9, 78.2, 81.9, 94.8, 127.4, 127.5, 128.2, 128.6; HRMS: calcd for $\mathrm{C}_{17} \mathrm{H}_{25} \mathrm{NO}_{4} \mathrm{Na}[\mathrm{M}+\mathrm{Na}]^{+} 330.1681$; found 330.1682. The ${ }^{1} \mathrm{H}$ NMR spectrum was complex due to the rotamers of $\mathbf{1 a}$.

\subsection{Synthesis of tert-butyl (1S,2S)-1,3-dihydroxy-1- phenylpropan-2ylcarbamate (3a)}

To a solution of $1 \mathbf{a}(2.0 \mathrm{~g}, 6.5 \mathrm{mmol})$ in $\mathrm{AcOH}-\mathrm{H}_{2} \mathrm{O}$ $(10: 1,5 \mathrm{~mL})$ was added $\mathrm{LiCl}(540 \mathrm{mg}, 13.0 \mathrm{mmol})$ at room temperature. The reaction mixture was stirred for $2 \mathrm{~h}$ at that temperature. Then, it was concentrated and co-evaporated with hexane $(50 \mathrm{~mL})$. The residue obtained was purified by column chromatography $(40 \%$ ethyl acetate in light petroleum) to afford the diol 3a (mixture of two rotamers) (1.2 g, 70\%) as an oil. $[\alpha]_{\mathrm{D}}^{25.5}=+35.5$ (c, 2.07 in $\mathrm{CHCl}_{3}$ ); IR (neat): 3406, 2978, 2933, 1693, 1504, 1454, 1367, $1168 \mathrm{~cm}^{-1} ;{ }^{1} \mathrm{H}$ NMR (500 MHz, $\left.\mathrm{CDCl}_{3}\right): \delta 1.30$ ( brs, 9H), 3.76-3.81 $(\mathrm{m}, 3 \mathrm{H}), 4.98$ (d, J = 2.5 Hz, 1H), 7.27-7.38 (m, 5H); ${ }^{13} \mathrm{C}$ NMR (125 MHz, $\mathrm{CDCl}_{3}$ ): 20.6, 28.2, 57.3, 62.0, 74.2, 80.1, 126.2, 127.9, 128.9, 141.4; HRMS: calcd for $\mathrm{C}_{14} \mathrm{H}_{21} \mathrm{NO}_{4} \mathrm{Na}[\mathrm{M}+\mathrm{Na}]^{+}$290.1368; found 290.1367.

\subsection{Synthesis of tert-butyl (1S,2S)-1-hydroxy-3- tosyloxy-1-phenylpropan-2ylcarbamate (4a)}

To a stirred solution of 3a (1.0 g, $3.74 \mathrm{mmol})$ and triethyl amine (5.6 mmol, $0.8 \mathrm{~mL}$ ) in dry $\mathrm{CH}_{2} \mathrm{Cl}_{2}$ $(20 \mathrm{~mL})$ at $0^{\circ} \mathrm{C}$ was added $p$-toluenesulphonyl chloride $(850 \mathrm{mg}, 4.49 \mathrm{mmol})$ in portions during $30 \mathrm{~min}$. After stirring for an additional $3 \mathrm{~h}$ at room temperature, the mixture was poured into ice-water. The organic layer was separated and the aqueous portion was extracted with $\mathrm{CH}_{2} \mathrm{Cl}_{2}(3 \times 50 \mathrm{~mL})$. The combined organic extracts was washed successively with aqueous $10 \%$ $\mathrm{HCl}(5 \mathrm{~mL})$, water $(5 \mathrm{~mL})$ and brine $(5 \mathrm{~mL})$, and finally dried $\left(\mathrm{Na}_{2} \mathrm{SO}_{4}\right)$. Removal of the solvent under reduced pressure followed by column chromatography of the residue obtained over silica gel $(20 \%$ ethyl acetate in light petroleum) afforded the monotosylated derivative 4a (mixture of two rotamers) $(1.25 \mathrm{~g}, 80 \%)$ as crystalline solid, $\mathrm{mp} 132-135^{\circ} \mathrm{C}$ ). $[\alpha]_{\mathrm{D}}^{25.0}=+26.3$ (c, 3.09 in $\mathrm{CHCl}_{3}$ ); IR (KBr): 3323, 3250, 3088, 1732, 1599, 1512, 1371, $1188 \mathrm{~cm}^{-1} ;{ }^{1} \mathrm{H}$ NMR $\left(500 \mathrm{MHz}, \mathrm{CDCl}_{3}\right)$ : $\delta 1.22(\mathrm{~s}, 9 \mathrm{H}), 2.38(\mathrm{~s}, 3 \mathrm{H}), 2.85$ (brs, $1 \mathrm{H}), 3.85-3.87$ $(\mathrm{m}, 2 \mathrm{H}), 4.09(\mathrm{dd}, J=6.5,10.0 \mathrm{~Hz}, 1 \mathrm{H}), 4.81(\mathrm{~d}$, $J=4.0 \mathrm{~Hz}, 1 \mathrm{H}), 7.17-7.22(\mathrm{~m}, 4 \mathrm{H}), 7.23-7.29(\mathrm{~m}$, $3 \mathrm{H}), 7.71(\mathrm{~d}, J=8.0 \mathrm{~Hz}, 2 \mathrm{H}) ;{ }^{13} \mathrm{C}$ NMR $(75 \mathrm{MHz}$, $\left.\mathrm{CDCl}_{3}\right): \delta 21.8,28.3,68.7,126.1,126.2,128.0,128.1$, 128.2, 128.5, 128.8, 130.1, 145.2; HRMS: calcd for $\mathrm{C}_{21} \mathrm{H}_{27} \mathrm{NO}_{6} \mathrm{SNa}[\mathrm{M}+\mathrm{Na}]^{+}$444.1457; found 444.1455.

\subsection{Synthesis of tert-butyl (1S,2S)-1-hydroxy-1- phenylpropan-2ylcarbamate (5a)}

A suspension of $\mathrm{LiAlH}_{4}(270 \mathrm{mg}, 7.3 \mathrm{mmol}$ in THF $(5 \mathrm{~mL})$ was added to a stirred solution of compound 4a $(1.0 \mathrm{~g}, 2.4 \mathrm{mmol})$ in THF $(10 \mathrm{~mL})$ at $0^{\circ} \mathrm{C}$. The reaction mixture was stirred additionally for $45 \mathrm{~min}$ at $0^{\circ} \mathrm{C}$. Then, $0.5 \mathrm{~mL}$ of $\mathrm{MeOH}$ was added to the reaction mixture followed by the addition of a saturated aqueous solution of sodium potassium tartrate $(10 \mathrm{~mL})$ and excess of diethyl ether $(40 \mathrm{~mL})$. The stirring was continued until complete precipitation at room temperature. The solids were filtered off and the filtrate was washed successively with aqueous $10 \% \mathrm{HCl}(10 \mathrm{~mL})$, water $(10 \mathrm{~mL})$ and brine $(10 \mathrm{~mL})$, and finally dried over $\mathrm{Na}_{2} \mathrm{SO}_{4}$. The organic solvent was evaporated under reduced pressure to afford the $\mathrm{N}-\mathrm{Boc}$ protected amino alcohol 5a (360 mg, 60\%) as white crystalline solid, mp $85-87^{\circ} \mathrm{C} .[\alpha]_{\mathrm{D}}^{25.5}=+24.9$ (c, 2.81 in $\mathrm{CHCl}_{3}$ ); IR (neat): 3403, 3375, 2980, $1684 \mathrm{~cm}^{-1} ;{ }^{1} \mathrm{H}$ NMR $(500 \mathrm{MHz}$, $\left.\mathrm{CDCl}_{3}\right): \delta 1.07(\mathrm{~d}, J=6.5 \mathrm{~Hz}, 3 \mathrm{H}), 1.40(\mathrm{~s}, 9 \mathrm{H}), 3.84$ $3.86(\mathrm{~m}, 1 \mathrm{H}), 4.54(\mathrm{~d}, J=6.0 \mathrm{~Hz}, 1 \mathrm{H}), 4.68-4.72(\mathrm{~m}$, 1H), 7.32-7.37 (m, 5H); ${ }^{13} \mathrm{NMR}\left(125 \mathrm{MHz}, \mathrm{CDCl}_{3}\right)$ : $\delta$ 17.0, 28.5, 55.0, 79.9, 126.8, 127.9, 128.4, 141.8; HRMS: calcd for $\mathrm{C}_{14} \mathrm{H}_{21} \mathrm{NO}_{3} \mathrm{Na}[\mathrm{M}+\mathrm{Na}]^{+} 274.1419$; found 274.1417 .

\subsection{Synthesis of (3,4-dimethoxyphenyl $)((R)-2,2-$ cyclohexylidene-1,3-dioxolan-4-yl)methanol $\left(\mathbf{l b}\right.$ and $\left.\mathbf{1} \boldsymbol{b}^{l}\right)$}

To a stirred solution of Grignard reagent at $0^{\circ} \mathrm{C}$ [prepared from 4-bromoveratrole (3 g, $14.0 \mathrm{mmol})$ with $\mathrm{Mg}$ (400 mg, $17.0 \mathrm{mmol}$ ) in THF (20 mL)] under $\mathrm{N}_{2}$ was added (R)-2,3-O-cyclohexylideneglyceraldehyde (B) $(2.9 \mathrm{~g}, 17 \mathrm{mmol})$ in THF $(30 \mathrm{~mL})$ over a period of $1 \mathrm{~h}$. The mixture was stirred for $3 \mathrm{~h}$ at room 
temperature. Saturated aqueous $\mathrm{NH}_{4} \mathrm{Cl}(10 \mathrm{~mL})$ was added to the reaction mixture followed by extraction with ether $(3 \times 70 \mathrm{~mL})$. The combined organic layer was washed with water $(3 \times 10 \mathrm{~mL})$ and brine $(5 \mathrm{~mL})$, and finally dried $\left(\mathrm{Na}_{2} \mathrm{SO}_{4}\right)$. The solvent was evaporated under reduced pressure and the residue was purified by column chromatography ( $15 \%$ ethyl acetate in light petroleum) over silica gel to afford an inseparable mixture of alcohols $\mathbf{1 b}$ and $\mathbf{1} \mathbf{b}^{\mathbf{1}}(2.5 \mathrm{~g}, 60 \%)$ in almost equal ratio.

2.7a IR (neat): $2920,2810,1690,1595,1420,1260$, $1163 \mathrm{~cm}^{-1} ;{ }^{1} \mathrm{H}$ NMR $\left(300 \mathrm{MHz}, \mathrm{CDCl}_{3}\right): \delta 1.36-1.38$ $(\mathrm{m}, 2 \mathrm{H}), 1.55-1.65(\mathrm{~m}, 8 \mathrm{H}), 3.64-3.66(\mathrm{~m}, 1 \mathrm{H}), 3.71-$ $3.75(\mathrm{~m}, 1 \mathrm{H}), 3.82(\mathrm{~s}, 3 \mathrm{H}), 3.84(\mathrm{~s}, 3 \mathrm{H}), 3.90-3.95(\mathrm{~m}$, $1 / 2 \mathrm{H}), 4.16-4.19(\mathrm{~m}, 1 \mathrm{H}), 4.21-4.28(\mathrm{~m}, 1 / 2 \mathrm{H}), 4.43$ $(\mathrm{d}, J=7.9 \mathrm{~Hz}, 1 / 2 \mathrm{H}), 4.78(\mathrm{~d}, J=4.2 \mathrm{~Hz}, 1 / 2 \mathrm{H}), 6.73$ $(\mathrm{d}, J=8.0 \mathrm{~Hz}, 1 \mathrm{H}), 6.78(\mathrm{~d}, J=8.0 \mathrm{~Hz}, 1 \mathrm{H}), 6.84$ (s, $1 \mathrm{H}) ;{ }^{13} \mathrm{C}\left(75 \mathrm{MHz}, \mathrm{CDCl}_{3}\right): \delta 23.8,24.0,25.1,34.7$, 34.9, 36.3, 36.4, 36.7, 55.9, 56.2, 63.1, 64.3, 65.4, 65.7, 72.5, 75.8, 79.2, 79.9, 109.1, 110.1, 118.3, 119.4, 132.5, 148.5, 149.1; HRMS: calcd for $\mathrm{C}_{17} \mathrm{H}_{24} \mathrm{O}_{5} \mathrm{Na}[\mathrm{M}+\mathrm{Na}]^{+}$ 331.1521 , found 331.1520 .

\subsection{Synthesis of (3,4-dimethoxyphenyl)((R)-2,2- cyclohexylidene-1,3-dioxolan-4-yl)methanone (2b)}

To a stirred solution of the crude mixture of alcohols $\mathbf{1 b}$ and $\mathbf{1 b}^{\mathbf{1}}$ (2.5 g, $8.1 \mathrm{mmol}$ ) in $\mathrm{CH}_{2} \mathrm{Cl}_{2}$, pyridinium chlorochromate $(2.4 \mathrm{~g}, 11.3 \mathrm{mmol})$ was added in the presence of excess of molecular sieves ( $4 \AA$ ) in one portion. The reaction mixture was stirred for another $30 \mathrm{~min}$ for complete conversion. Excess diethyl ether $(40 \mathrm{~mL})$ was added to the reaction mixture followed by filtration. The filtrate was washed successively with aqueous $10 \% \mathrm{HCl}(10 \mathrm{~mL})$, water $(10 \mathrm{~mL})$ and brine $(10 \mathrm{~mL})$, and finally dried over $\mathrm{Na}_{2} \mathrm{SO}_{4}$. The solvent was evaporated under reduced pressure and the residue obtained was purified by column chromatography $(10 \%$ ethyl acetate in light petroleum) to afford pure keto compound $\mathbf{2 b}(2.1 \mathrm{~g}, 85 \%)$ as a viscous liquid.

2.8a IR (neat): 2936, 2806, 1693, 1595, 1514, 1446, $1263,1163 \mathrm{~cm}^{-1} ;{ }^{1} \mathrm{H}$ NMR $\left(500 \mathrm{MHz}, \mathrm{CDCl}_{3}\right): \delta 1.40$ $1.43(\mathrm{~m}, 2 \mathrm{H}), 1.54-1.72(\mathrm{~m}, 8 \mathrm{H}), 3.95(\mathrm{~s}, 3 \mathrm{H}), 3.96$ (s, 3H), 4.25-4.31 (m, 2H), $5.22(\mathrm{~m}, 1 \mathrm{H}), 6.90-6.94$ $(\mathrm{m}, 2 \mathrm{H}), 7.06-7.10(\mathrm{~m}, 1 \mathrm{H}) ;{ }^{13} \mathrm{C}$ NMR $(125 \mathrm{MHz}$, $\left.\mathrm{CDCl}_{3}\right): \delta 24.0,252,35.3,35.6,56.2,66.2,77.5,110.2$, 110.7, 111.7, 119.3, 124.1, 134.4, 148.5, 153.8, 195.5; HRMS: calcd for $\mathrm{C}_{17} \mathrm{H}_{22} \mathrm{O}_{5} \mathrm{Na}[\mathrm{M}+\mathrm{Na}]^{+} 329.1365$, found 329.1364 .
2.9 Synthesis of $(R)-(3,4-$ dimethoxyphenyl)((R)-2,2cyclohexylidene-1,3-dioxolan-4-yl)methanol (1b)

A suspension of $\mathrm{LiAlH}_{4}(740 \mathrm{mg}, 19.5 \mathrm{mmol})$ in THF $(10 \mathrm{~mL})$ was added drop-wise to a stirred solution of the keto compound $2 \mathbf{b}(2.0 \mathrm{~g}, 6.5 \mathrm{mmol})$ in THF $(10 \mathrm{~mL})$ at $-78^{\circ} \mathrm{C}$. The reaction mixture was stirred at this temperature for another $30 \mathrm{~min}$. $\mathrm{MeOH}(1 \mathrm{~mL})$ was added to the reaction mixture and the temperature was gradually raised to $0^{\circ} \mathrm{C}$. At this temperature a saturated aqueous solution of sodium potassium tartrate $(10 \mathrm{~mL})$ and excess of diethyl ether $(50 \mathrm{~mL})$ was added. The stirring was continued until complete precipitation. It was filtered and the filtrate was successively washed with aqueous $10 \% \mathrm{HCl}(10 \mathrm{~mL})$, water $(10 \mathrm{~mL})$ and brine $(10 \mathrm{~mL})$, and finally dried over $\mathrm{Na}_{2} \mathrm{SO}_{4}$. The organic solvent was evaporated under reduced pressure and the residue obtained was purified by column chromatography ( $10 \%$ ethyl acetate in light petroleum) to afford the syn isomer $1 \mathbf{b}(1.6 \mathrm{~g}, 80 \%)$ as a viscous liquid. $[\alpha]_{\mathrm{D}}^{26.8}=$ -17.2 (c, 8.1 in $\mathrm{CHCl}_{3}$ ); IR (neat): 3485, 2997, 2935, 1593, 1514, 1263, $1161 \mathrm{~cm}^{-1} ;{ }^{1} \mathrm{H}$ NMR $(500 \mathrm{MHz}$, $\left.\mathrm{CDCl}_{3}\right): \delta 1.38-1.41(\mathrm{~m}, 2 \mathrm{H}), 1.54-1.68(\mathrm{~m}, 8 \mathrm{H}), 3.67$ $(\mathrm{dd}, J=5.5,8.5 \mathrm{~Hz}, 1 \mathrm{H}), 3.76-3.78(\mathrm{~m}, 1 \mathrm{H}), 3.76(\mathrm{~s}$, $3 \mathrm{H}), 3.78(\mathrm{~s}, 3 \mathrm{H}), 4.17(\mathrm{dd}, J=6.5,13.5 \mathrm{~Hz}, 1 \mathrm{H})$, $4.45(\mathrm{~d}, J=8.0 \mathrm{~Hz}, 2 \mathrm{H}), 6.80-6.83(\mathrm{~m}, 2 \mathrm{H}), 6.86-$ $6.91(\mathrm{~m}, 1 \mathrm{H}) ;{ }^{13} \mathrm{C}$ NMR $\left(125 \mathrm{MHz}, \mathrm{CDCl}_{3}\right): \delta 23.9$, 24.3, 25.3, 35.1, 36.5, 36.9, 56.09, 65.9, 76.2, 80.1, 110.2, 110.9, 111.3, 119.6, 132.5, 149.4; HRMS: calcd for $\mathrm{C}_{17} \mathrm{H}_{24} \mathrm{O}_{5} \mathrm{Na}[\mathrm{M}+\mathrm{Na}]^{+}$331.1521, found 331.1520.

\subsection{Synthesis of $(R)-4-((R)-(4-m e t h o x y b e n z y l o x y)$ \\ (3,4-dimethoxyphenyl)methyl)-2,2-cyclohexylidine-1,3- dioxolane $(\mathbf{3 b})$}

To a stirred suspension of sodium hydride $(350 \mathrm{mg}$, $60 \%$ dispersion in oil, $14.6 \mathrm{mmol})$ in dry THF $(20 \mathrm{~mL})$ was added drop-wise to a solution of the alcohol $\mathbf{1 b}$ $(1.5 \mathrm{~g}, 4.9 \mathrm{mmol})$ in dry THF $(10 \mathrm{~mL})$ at $0^{\circ} \mathrm{C}$ under $\mathrm{N}_{2}$. Then, a solution of $p$-methoxy benzyl bromide (1.2 g, $5.8 \mathrm{mmol})$ in dry THF $(20 \mathrm{~mL})$ was added drop-wise at $0^{\circ} \mathrm{C}$ over $30 \mathrm{~min}$. The reaction was continued to stir at room temperature for $3 \mathrm{~h}$. The reaction mixture was then carefully quenched with ice-water. After removal of most of THF under reduced pressure, the resulting residue was extracted with diethyl ether $(3 \times 50 \mathrm{~mL})$. The combined ether extract was washed successively with water $(3 \times 10 \mathrm{~mL})$ and brine $(5 \mathrm{~mL})$, and finally dried $\left(\mathrm{Na}_{2} \mathrm{SO}_{4}\right)$. Removal of the solvent under reduced pressure afforded a viscous liquid, which was purified by column chromatography (5\% ethyl acetate in light petroleum) over silica gel to afford $p$-methoxybenzyl protected ether $\mathbf{3 b}(1.4 \mathrm{~g}, 70 \%)$ as a viscous oil. IR 
(neat): 3009, 2935, 2862, 1612, 1514, 1464, 1249, $1163 \mathrm{~cm}^{-1} ;{ }^{1} \mathrm{H}$ NMR (500 MHz, $\mathrm{CDCl}_{3}$ ): $\delta 1.30-1.34$ (m, 2H), 1.40-1.56 (m, 8H), $3.45(\mathrm{dd}, J=6.5,8.5 \mathrm{~Hz}$, $1 \mathrm{H}), 3.56-3.59(\mathrm{~m}, 1 \mathrm{H}), 3.72(\mathrm{~s}, 3 \mathrm{H}), 3.79(\mathrm{~s}, 3 \mathrm{H}), 3.81$ (s, 3H), 4.13-4.16 (m, 1H), $4.25(\mathrm{dd}, J=6.5,14 \mathrm{~Hz}$, $1 \mathrm{H}), 4.44-4.52(\mathrm{~m}, 2 \mathrm{H}), 6.76-6.84(\mathrm{~m}, 5 \mathrm{H}), 7.16(\mathrm{~d}$, $J=8.5 \mathrm{~Hz}, 2 \mathrm{H}) ;{ }^{13} \mathrm{C} \mathrm{NMR}\left(125 \mathrm{MHz}, \mathrm{CDCl}_{3}\right): \delta 23.9$, 24.1, 25.3, 35.3, 36.4, 55.4, 55.9, 56.0, 65.8, 69.8, 78.8, 81.8, 110.6, 110.7, 111.0, 113.8, 113.9, 114.1, 128.7, 129.6, 130.4, 130.7, 149.1, 149.2, 159.3; HRMS: calcd for $\mathrm{C}_{25} \mathrm{H}_{32} \mathrm{O}_{6} \mathrm{Na}[\mathrm{M}+\mathrm{Na}]^{+}$451.2097, found 451.2098.

2.11 Synthesis of (2R,3R)-3-(4-methoxybenzyloxy)-3(3,4-dimethoxyphenyl)propane-1,2-diol (4b)

The compound $\mathbf{3 b}(1.4 \mathrm{~g}, 3.27 \mathrm{mmol})$ was stirred with $80 \%$ aqueous acetic acid $(5 \mathrm{~mL})$ at $40^{\circ} \mathrm{C}$ for $2 \mathrm{~h}$ (monitored by TLC). Acetic acid was removed under reduced pressure and co-evaporated with toluene. The crude residue obtained was chromatographed $(20 \%$ ethyl acetate in light petroleum) over silica gel to afford the pure diol $\mathbf{4 b}(800 \mathrm{mg}, 70 \%)$ as a viscous liquid. $[\alpha]_{\mathrm{D}}^{25.6}=-63.4$ (c, 5.2 in $\mathrm{CHCl}_{3}$ ); IR (neat): 3464, 2958, 2837, 1514, 1464, 1251, $1030 \mathrm{~cm}^{-1} ;{ }^{1} \mathrm{H}$ NMR $\left(500 \mathrm{MHz}, \mathrm{CDCl}_{3}\right): \delta 3.34(\mathrm{dd}, J=5.0,11.0 \mathrm{~Hz}, 1 \mathrm{H})$, $3.51(\mathrm{dd}, J=3.5,12.0 \mathrm{~Hz}, 1 \mathrm{H}), 3.73-3.78(\mathrm{~m}, 1 \mathrm{H})$, $3.80(\mathrm{~s}, 3 \mathrm{H}), 3.88(\mathrm{~s}, 3 \mathrm{H}), 3.89(\mathrm{~s}, 3 \mathrm{H}), 4.21(\mathrm{~d}, J=$ $11.0 \mathrm{~Hz}, 1 \mathrm{H}), 4.33(\mathrm{~d}, J=8.0 \mathrm{~Hz}, 1 \mathrm{H}), 4.41(\mathrm{~d}, J=$ $11.0 \mathrm{~Hz}, 1 \mathrm{H}), 6.86-6.91$ (m, 5H), 7.19 (d, $J=8.5 \mathrm{~Hz}$, $2 \mathrm{H}) ;{ }^{13} \mathrm{C} \mathrm{NMR}\left(125 \mathrm{MHz}, \mathrm{CDCl}_{3}\right): \delta 55.4,56.0,56.1$, 62.6, 70.3, 75.7, 81.7, 110.2, 111.2, 114.1, 120.5, 129.7, 129.8, 129.9, 130.5, 149.2, 149.4, 159.5; HRMS: calcd for $\mathrm{C}_{19} \mathrm{H}_{24} \mathrm{O}_{6}[\mathrm{M}+\mathrm{Na}]^{+}$371.1471, found 371.1472.

2.12 Synthesis of (2R,3R)-3-(4-methoxybenzyloxy)-2hydroxy-3-(3,4-dimethoxyphenyl)propyl

4-methylbenzenesulphonate $(\mathbf{5 b})$

To a stirred solution of $\mathbf{4 b}(800 \mathrm{mg}, 2.3 \mathrm{mmol})$ and excess of pyridine $(3 \mathrm{~mL})$ in dry $\mathrm{CH}_{2} \mathrm{Cl}_{2}(20 \mathrm{~mL})$ at $0^{\circ} \mathrm{C}$ was added $p$-toluenesulphonyl chloride $(530 \mathrm{mg}$, $2.75 \mathrm{mmol}$ ) in portions during $30 \mathrm{~min}$ under $\mathrm{N}_{2}$. After stirring for another $12 \mathrm{~h}$ at room temperature, the mixture was poured into ice-water. The organic layer was separated and the aqueous portion was extracted with $\mathrm{CH}_{2} \mathrm{Cl}_{2}(3 \times 50 \mathrm{~mL})$. The combined organic extract was washed successively with aqueous $10 \% \mathrm{HCl}$ $(5 \mathrm{~mL})$, water $(5 \mathrm{~mL})$ and brine $(5 \mathrm{~mL})$, and finally dried $\left(\mathrm{Na}_{2} \mathrm{SO}_{4}\right)$. Removal of the solvent under reduced pressure followed by column chromatography of the residue (10\% ethyl acetate in light petroleum) over silica gel afforded the monotosylated derivative $\mathbf{5 b}(810 \mathrm{mg}$,
$70 \%)$ as an oil. $[\alpha]_{\mathrm{D}}^{25.8}=-37.4$ (c, 3.0 in $\mathrm{CHCl}_{3}$ ); IR (neat): 3520, 2955, 2935, 2837, 1612, 1514, 1454, 1359, 1249, $1176 \mathrm{~cm}^{-1} ;{ }^{1} \mathrm{H}$ NMR (500 MHz, $\mathrm{CDCl}_{3}$ ): $\delta 2.43(\mathrm{~s}, 3 \mathrm{H}), 3.80(\mathrm{~s}, 3 \mathrm{H}), 3.83-3.86(\mathrm{~m}, 2 \mathrm{H}), 3.88(\mathrm{~s}$, $3 \mathrm{H}), 3.90$ (s, 3H), 3.97 (dd, $J=2.5,9.5 \mathrm{~Hz}, 1 \mathrm{H}), 4.20$ $(\mathrm{d}, J=11.0 \mathrm{~Hz}, 1 \mathrm{H}), 4.36-4.40(\mathrm{~m}, 2 \mathrm{H}), 6.84-6.87$ $(\mathrm{m}, 5 \mathrm{H}), 7.16(\mathrm{~d}, J=8.5 \mathrm{~Hz}, 2 \mathrm{H}), 7.30(\mathrm{~d}, J=8.0 \mathrm{~Hz}$, $2 \mathrm{H}), 7.73(\mathrm{~d}, J=8.0 \mathrm{~Hz}, 2 \mathrm{H}) ;{ }^{13} \mathrm{C}$ NMR $(125 \mathrm{MHz}$, $\left.\mathrm{CDCl}_{3}\right): \delta 21.8,55.4,56.0,56.1,69.9,70.6,73.5,80.6$, $110.3,111.4,114.0,114.1,120.2,128.0,128.1,129.7$, 129.8, 129.9, 130.0, 132.9, 144.9, 149.4, 149.5, 159.6; HRMS: calcd for $\mathrm{C}_{26} \mathrm{H}_{30} \mathrm{O}_{8} \mathrm{SNa}[\mathrm{M}+\mathrm{Na}]^{+}$525.1559, found 525.1559 .

\subsection{Synthesis of (1R,2R)-1-(4-methoxybenzyloxy)-1-} (3,4-dimethoxyphenyl)propan-2-ol $(\boldsymbol{6} \boldsymbol{b})$

A suspension of $\mathrm{LiAlH}_{4}(5.0 \mathrm{mmol})$ in THF $(5 \mathrm{~mL})$ was added drop-wise to the stirred solution of compound 5b $(800 \mathrm{mg}, 1.6 \mathrm{mmol})$ in THF $(5 \mathrm{~mL})$ at $0^{\circ} \mathrm{C}$ under $\mathrm{N}_{2}$. Then the reaction mixture was stirred for $45 \mathrm{~min}$ at room temperature. Then, $0.5 \mathrm{~mL}$ of $\mathrm{MeOH}$ was added to the reaction mixture followed by the addition of a saturated aqueous solution of sodium potassium tartrate $(10 \mathrm{~mL})$ and excess of diethyl ether $(40 \mathrm{~mL})$. The stirring was continued until complete precipitation at room temperature. The solids were filtered off and the filtrate was washed successively with aqueous $10 \% \mathrm{HCl}$, water $(10 \mathrm{~mL})$ and brine $(10 \mathrm{~mL})$, and finally dried over $\mathrm{Na}_{2} \mathrm{SO}_{4}$. The organic solvent was evaporated under reduced pressure to afford the alcohol $\mathbf{6 b}(420 \mathrm{mg}$, $80 \%)$ as an oil.

2.13a $[\alpha]_{\mathrm{D}}^{25.8}=68.7$ (c, 2.2 in $\mathrm{CHCl}_{3}$ ); IR (neat): 3550, 2935, 2837, 1519, 1467, $1248 \mathrm{~cm}^{-1} ;{ }^{1} \mathrm{H}$ NMR $\left(500 \mathrm{MHz}, \mathrm{CDCl}_{3}\right): \delta 0.95(\mathrm{~d}, J=6.5 \mathrm{~Hz}, 3 \mathrm{H}), 3.80(\mathrm{~s}$, $3 \mathrm{H}), 3.83-3.87(\mathrm{~m}, 1 \mathrm{H}), 3.89(\mathrm{~s}, 3 \mathrm{H}), 3.90(\mathrm{~s}, 3 \mathrm{H}), 3.98$ $(\mathrm{d}, J=8.5 \mathrm{~Hz}, 1 \mathrm{H}), 4.20(\mathrm{~d}, J=11.0 \mathrm{~Hz}, 1 \mathrm{H}), 4.38$ $(\mathrm{d}, J=11.5 \mathrm{~Hz}, 1 \mathrm{H}), 6.86-6.90(\mathrm{~m}, 5 \mathrm{H}), 7.20(\mathrm{~d}, J=$ $8.5 \mathrm{~Hz}, 2 \mathrm{H}) ;{ }^{13} \mathrm{C} \mathrm{NMR}\left(125 \mathrm{MHz}, \mathrm{CDCl}_{3}\right): \delta 18.2,29.8$, 55.4, 56.0, 56.1, 70.3, 71.5, 86.8, 110.3, 111.1, 114.0, 114.1, 120.7, 129.8, 130.2, 131.3, 149.2, 149.4, 159.5; HRMS: calcd for $\mathrm{C}_{19} \mathrm{H}_{25} \mathrm{O}_{5}[\mathrm{M}+\mathrm{H}]^{+} 333.1702$, found 333.1693 .

\subsection{Synthesis of ((R)-2,2-cyclohexylidine-1,} 3-dioxolan-4-yl)methyl 4-methylbenzenesulphonate (2c)

To a stirred solution of (R)-2,3-O-cyclohexylideneglyceraldehyde (B) (850 mg, $5 \mathrm{mmol}$ ) in $\mathrm{MeOH}(8 \mathrm{~mL})$ $\mathrm{NaBH}_{4}(290 \mathrm{mg}, 7.5 \mathrm{mmol})$ was added portion-wise 
at $0^{\circ} \mathrm{C}$. The reaction mixture was stirred for another $30 \mathrm{~min}$ (monitored by TLC). Water (1 mL) was added to the reaction mixture and $\mathrm{MeOH}$ was evaporated under reduced pressure. The remaining residue was extracted with diethyl ether $(3 \times 40 \mathrm{~mL})$ and combined organic layer was washed successively with water $(10 \mathrm{~mL})$ and brine $(10 \mathrm{~mL})$, and finally dried over $\mathrm{Na}_{2} \mathrm{SO}_{4}$ to afford the known alcohol 1c (80\%, $680 \mathrm{mg})$. The crude alcohol was sufficient pure to use in the next step.

2.14a Compound 2c (920 mg, 75\%) was prepared form the alcohol 1c $(650 \mathrm{mg}, 3.8 \mathrm{mmol})$ following the similar procedure as described for $\mathbf{5 b}$. IR (neat): 2937, 2862, 1599, 1450, 1365, $1178 \mathrm{~cm}^{-1} ;{ }^{1} \mathrm{H}$ NMR $\left(300 \mathrm{MHz}, \mathrm{CDCl}_{3}\right): \delta 1.34-1.39(\mathrm{~m}, 2 \mathrm{H}), 1.49-1.51(\mathrm{~m}$, $8 \mathrm{H}), 2.42(\mathrm{~s}, 3 \mathrm{H}), 3.73(\mathrm{dd}, J=5.0 \mathrm{~Hz}, 8.7 \mathrm{~Hz}, 1 \mathrm{H})$, 3.92-3.97 (m, 2H), 3.98-4.02 (m, 1H), 4.23-4.27 (m, $1 \mathrm{H}), 7.33(\mathrm{~d}, J=8.0 \mathrm{~Hz}, 2 \mathrm{H}), 7.76(\mathrm{~d}, J=8.1 \mathrm{~Hz}$, $2 \mathrm{H}) ;{ }^{13} \mathrm{C} \mathrm{NMR}\left(75 \mathrm{MHz}, \mathrm{CDCl}_{3}\right): \delta 21.7,23.97,23.9$, 25.1, 34.7, 36.4, 65.9, 69.8, 72.6, 110.7, 128.0, 129.9, 132.7, 145.1; HRMS: calcd for $\mathrm{C}_{16} \mathrm{H}_{22} \mathrm{O}_{5} \mathrm{~S}[\mathrm{M}+\mathrm{Na}]^{+}$ 349.1086, found 349.1086.

\subsection{Synthesis of 9-(((R)-2,2-cyclohexylidine-1,3- dioxolan-4-yl)methyl-9H-purin-6-amine (3c)}

A mixture of adenine (400 mg, $3.0 \mathrm{mmol}$ ), powdered anhydrous $\mathrm{K}_{2} \mathrm{CO}_{3}(550 \mathrm{mg}, 4.0 \mathrm{mmol})$ and 18-crown$6(1.0 \mathrm{~g}, 4.0 \mathrm{mmol})$ in dry DMF $(3 \mathrm{~mL})$ was stirred for $15 \mathrm{~min}$ at $80^{\circ} \mathrm{C}$ under argon. Then, a solution of the tosylate $2 \mathbf{c}(650 \mathrm{mg}, 2.0 \mathrm{mmol})$ in dry DMF $(2.0 \mathrm{~mL})$ was added drop-wise and the reaction mixture was heated at $80^{\circ} \mathrm{C}$ for $4 \mathrm{~h}$. The mixture was allowed to come to the room temperature and concentrated to dryness under reduced pressure. The residue obtained was purified by column chromatography $\left(\mathrm{CH}_{2} \mathrm{Cl}_{2}-\mathrm{MeOH}\right.$, $15: 1)$ over silica gel to give the pure compound $\mathbf{3 c}$ (370 mg, 65\%) as crystalline solid, $\mathrm{mp} 210-212^{\circ} \mathrm{C}$. IR (KBr): 3346, 3290, 2937, 2887, 1604, 1475, 1419, $1309,1107 \mathrm{~cm}^{-1} ;{ }^{1} \mathrm{H}$ NMR $\left(300 \mathrm{MHz}, \mathrm{CDCl}_{3}\right): \delta 1.38-$ $1.40(\mathrm{~m}, 2 \mathrm{H}), 1.55-1.59(\mathrm{~m}, 8 \mathrm{H}), 3.67(\mathrm{dd}, J=5.9$, $8.6 \mathrm{~Hz}, 1 \mathrm{H}), 4.10(\mathrm{dd}, J=6.4,8.7 \mathrm{~Hz}, 1 \mathrm{H}), 4.25(\mathrm{dd}$, $J=5.9,14.2 \mathrm{~Hz}, 1 \mathrm{H}), 4.44-4.50(\mathrm{~m}, 2 \mathrm{H}), 5.64$ (brs, 2H), $7.94(\mathrm{~s}, 1 \mathrm{H}), 8.35(\mathrm{~s}, 1 \mathrm{H}) ;{ }^{13} \mathrm{C}$ NMR $(125 \mathrm{MHz}$, $\left.\mathrm{CDCl}_{3}\right): \delta 23.7,24.0,25.1,34.7,36.5,45.7,66.1,70.5$, $73.7,110.8,141.6,153.1$.

\subsection{Synthesis of (R)-3-(6-amono-9H-purin-9-yl) propane-1,2-diol (4c)}

To the stirred solution of the compound $\mathbf{3 c}(580 \mathrm{mg}$, $2 \mathrm{mmol})$ in $\mathrm{MeOH}(3 \mathrm{~mL}), 0.2 \mathrm{~mL}$ conc. $\mathrm{HCl}$ was added. The reaction mixture was stirred for $0.5 \mathrm{~h}$. Then the solvent was removed under reduced pressure and $\mathrm{CH}_{2} \mathrm{Cl}_{2}(8 \mathrm{~mL})$ was added to it. The reaction mixture was kept aside for one hour for complete precipitation of the compound $\mathbf{4 c}$. The solids were filtered off and was washed carefully with $\mathrm{CH}_{2} \mathrm{Cl}_{2}(\sim 10 \mathrm{~mL})$ to get the pure diol $4 \mathbf{c}(330 \mathrm{mg}, 80 \%)$ as a white crystalline solid, $\mathrm{mp} 215-217^{\circ} \mathrm{C}$. IR $3379,3300,2733,1668,1510,1354$, $1041 \mathrm{~cm}^{-1} .{ }^{1} \mathrm{H}$ NMR (500 MHz, DMSO-d 6 ): $\delta 3.33$ $(\mathrm{dd}, J=6.5,11.0 \mathrm{~Hz}, 1 \mathrm{H}), 3.42(\mathrm{dd}, J=5.0,11.0 \mathrm{~Hz}$, $1 \mathrm{H}), 3.82(\mathrm{dd}, J=9.0,14.0 \mathrm{~Hz}, 1 \mathrm{H}), 4.09-4.14(\mathrm{~m}$, $1 \mathrm{H}), 4.38(\mathrm{dd}, J=2.5,14.0 \mathrm{~Hz}, 1 \mathrm{H}), 8.42(\mathrm{~s}, 1 \mathrm{H}), 8.49$ (s, $1 \mathrm{H}) ;{ }^{13} \mathrm{C}$ NMR $(125 \mathrm{MHz}$, DMSO-d 6 ): $\delta 63.8,70.1$, 70.3, 145.1, 145.3, 149.2, 150.5 .

\section{$2.17 X$-ray crystallographic data of $\mathbf{3 c}$}

A yellowish plate shaped crystal $(0.16 \times 0.14 \times$ $0.10 \mathrm{~mm}$ ) of $\mathbf{3 c}$ was analysed. Empirical formula $\mathrm{C}_{14} \mathrm{H}_{22} \mathrm{~N}_{5} \mathrm{O}_{2}$, Chemical formula weight $=292.37$, monoclinic, space group P2(1), $a=10.7820(17), b=$ 8.5518(14), $c=15.817(3) \AA$. $298 \mathrm{~K}, Z=4 . \rho_{\text {cal }}=1.369 \mathrm{gcm}^{-3} \cdot F(000)=628$, $\lambda(\mathrm{Mo}-\mathrm{K} \alpha)=0.71073 \AA, \mu \mathrm{MoK} \alpha / \mathrm{mm}^{-1}=0.095$, $2 \theta \max =43.92^{\circ}, 10226$ total reflections, 3461 unique reflections, 3461 observed [(I $>2 \sigma$ (I)]; 382 parameters; $\mathrm{R}_{\text {int }}=0.0476, \mathrm{wR}_{2}=0.1247[\mathrm{I}>2 \sigma(\mathrm{I})] ; \mathrm{R}_{1}=0.0419$; $\mathrm{wR}_{2}=0.1164$ (all data) with $\mathrm{GOF}=0.962$.

\section{Results and discussion}

Our synthetic strategy was initiated with nucleophilic addition of phenyl magnesium bromide to commercially available Garner's aldehyde (A) to produce an inseparable mixture of two isomeric alcohols $\mathbf{1 a}$ and $1 \mathbf{a}^{1}$ in a ratio of 1:1 (scheme 1). Each isomer shows two rotamers which made the ${ }^{1} \mathrm{H}$ NMR spectrum very complicated. Ratio was determined by GC. The crude alcohol was subjected to PCC oxidation to furnish the ketone $\mathbf{2 a}$ in $80 \%$ yield. Compound $\mathbf{2 a}$ was also a mixture of two rotamers. Reduction of $\mathbf{2 a}$ with $\mathrm{LiAlH}_{4}$ in THF furnished the syn alcohol 1a exclusively without a trace of any anti isomer $\mathbf{1 a}^{\mathbf{1}}$ (scheme 1). ${ }^{5}$ Due to the presence of rotamers the NMR spectra of the compounds described showed complicated patterns which has already been explained by Nishida et al. ${ }^{5}$ in details.

The high selectivity of the nucleophilic addition of hydride to carbonyl moiety ${ }^{6}$ in $\mathbf{2 a}$ may be explained with the analogy as reported by Chikasita. ${ }^{6 a}$ The nucleophilic addition depends not only on the nucleophile or the chiral environment around but also on the metal ion used. In general, the strong chelating effect of 


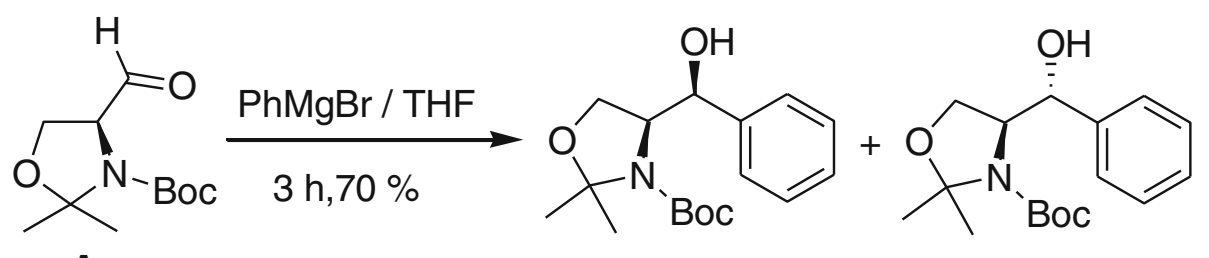

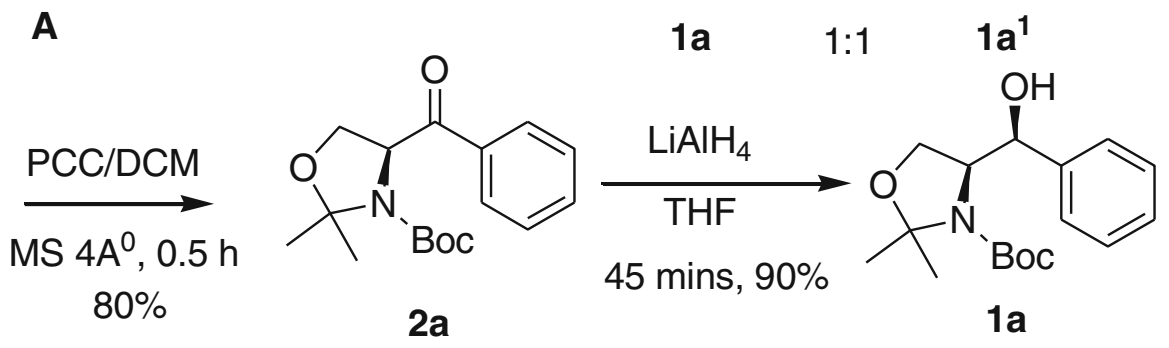

Scheme 1. Synthesis of 1-hydroxy-phenethylamine derivative.

the counter ion lithium favours the $\beta$-chelation transition state $\mathbf{C}$ over the $\alpha$-chelation transition state $\mathbf{D}$ (figure 1). In case of $\mathbf{2 a}$ the $\alpha$-chelation transition state F is totally disfavoured due to the presence of the bulky N-Boc group resulting in only the syn alcohol 1a through the $\beta$-chelation transition state $\mathbf{E}$.

However, a recent report by Hajra et al..$^{\text {a }}$ revealed during the asymmetric synthesis of a dopamine D1 agonist that 1-hydroxy-phenethylamine derivative 1a could be prepared in one step using CuI.DMS complex. synSelective addition to Garner aldehyde has been reported by Ganem et al. ${ }^{7 \mathrm{~b}}$ during the synthesis of a potent glucosylceramide synthase inhibitor. In the comprehensive review by Mengel and Reiser, ${ }^{7 \mathrm{c}}$ the necleophilic addition to Garner aldehyde has been discussed in details.

Compound 1a was then deprotected using aqueous acetic acid in the presence of $\mathrm{LiCl}$ to afford $\mathbf{3 a}$ in good yield. The diol 3a was selectively monotosylated ${ }^{8}$ using tosyl chloride in the presence of excess triethylamine in dichloromethane to afford $\mathbf{4 a}$ in $80 \%$ yield. The compound 4a was reduced with $\mathrm{LiAlH}_{4}$ in THF to produce the substituted N-Boc protected 1-phenyl 2amino alcohol 5a in good yield (scheme 2). The compound $\mathbf{5 a}$ has already been transformed to norephedrine (6a) and ephedrine (7a). ${ }^{2 c, 9}$ So, a formal synthesis of norephedrine has been achieved.

The important N-protected amino alcohol 3a has also been used by Baruwa et al..$^{10}$ for the synthesis of different biologically active natural products such as chloramphenicol A. Stereoselective synthesis of chiral $\beta$ hydroxy- $\alpha$-amidoester from 1a could easily be obtained as reported by Rao et al. through simple chemical transformations. ${ }^{11}$

Our next target was the synthesis of virolin (7b), a biologically active neolignan ${ }^{12}$ or its advanced intermediate starting from easily accessible (R)-2,3-Ocyclohexylidine glyceraldehydes $(\mathbf{B})$ as a source of chiral pool. Thus, freshly prepared Grignard reagent (ArMgBr) from 4-bromo veratrole was added to the aldehyde $\mathbf{B}$ to derive an inseparable mixture of two isomeric alcohols $\mathbf{1 b}$ and $\mathbf{1 b}^{\mathbf{1}}$ in a ratio of $1: 1$ (scheme 3). The crude alcohol was subjected to PCC oxidation to produce the ketone $\mathbf{2} \mathbf{b}$. The ketone $\mathbf{2 b}$ was reduced by $\mathrm{LiAlH}_{4}$ in THF to afford an inseparable mixture of alcohols (syn:anti $=95: 5$ ) which was directly treated with the $p$-methoxybenzyl bromide in the presence of $\mathrm{NaH}$ and a catalytic amount of HMPA to afford the PMB-protected aryl ether $\mathbf{3 b}$ after column chromatography (10\% ethyl acetate in light petroleum).
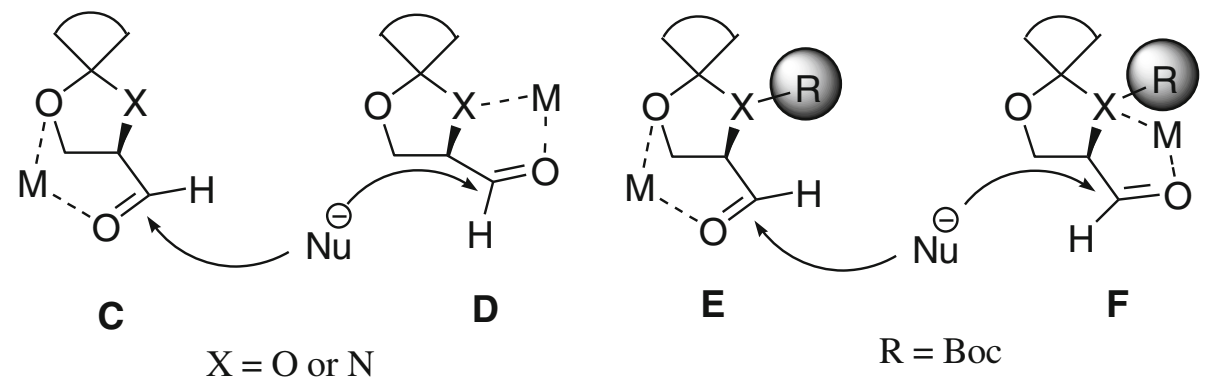

Figure 1. Transition states in nucleophilic addition. 


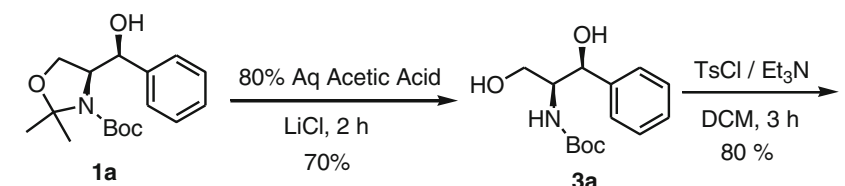

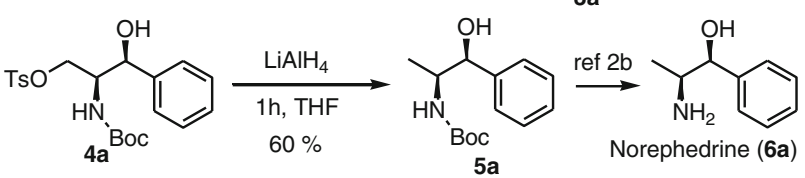<smiles>CC(NCc1ccccc1)C(O)c1ccccc1</smiles>

Scheme 2. Formal synthesis of norephedrine and ephedrine.

In this case, the slightly lower selectivity in nucleophilic addition was observed due to the probability of $\alpha$-chelation ( $\mathrm{X}=\mathrm{O}$, figure 1) involving counter ion lithium in transition state $\mathbf{D}$ although the major product was formed through the transition state $\mathbf{C} .^{6 a}$ The aryl ether $\mathbf{3 b}$ on treatment with $80 \%$ aqueous acetic acid at $40^{\circ} \mathrm{C}$ afforded the diol $\mathbf{4 b}$. The primary hydroxy group of the diol $\mathbf{4 b}$ was selectively monotosylated using tosyl chloride with excess of pyridine in DCM furnishing the monotosylated alcohol $\mathbf{5 b}$. The alcohol $\mathbf{5 b}$ was treated with $\mathrm{LiAlH}_{4}$ in THF at room temperature to afford the alcohol $\mathbf{6 b}$ in $80 \%$ yield.

Here, it is noteworthy to mention that a class of 4hydroxy-7,8-diol $\mathbf{8 b}$ could easily be synthesized from the intermediate $\mathbf{6 b}$. These diols themselves are naturally occurring compounds and have considerable medicinal applications such as treatment of disease due to malnutrition in children. ${ }^{13}$ Now, the monoprotected diol $\mathbf{6 b}$ could be converted into the threo isomer of Virolin (7b) as reported by Zanardi ${ }^{12 b}$ and $\mathrm{Xia}^{12 \mathrm{~d}}$ with the inversion of the stereochemistry at C8. We extended the synthetic strategy towards the<smiles></smiles>

B

$1 b$ $1 b^{1}$<smiles>COc1ccc([C@@H](O)C2OC3(CCCCC3)OCC2C(=O)c2cc(C(=O)C3COC4(CCCCC4)O3)ccc2OC)cc1OC</smiles>

2b

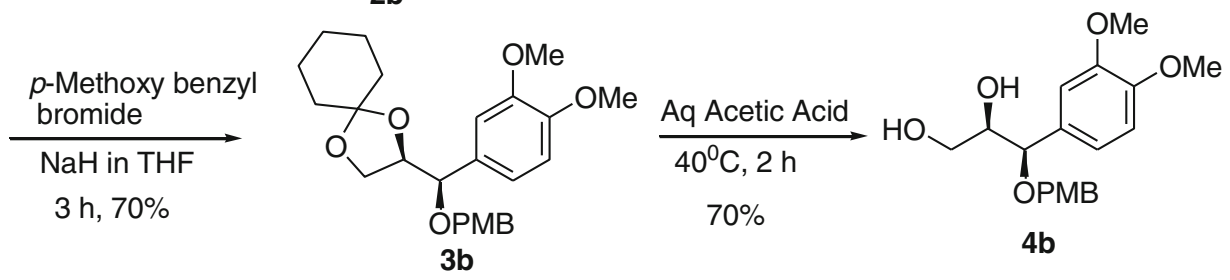

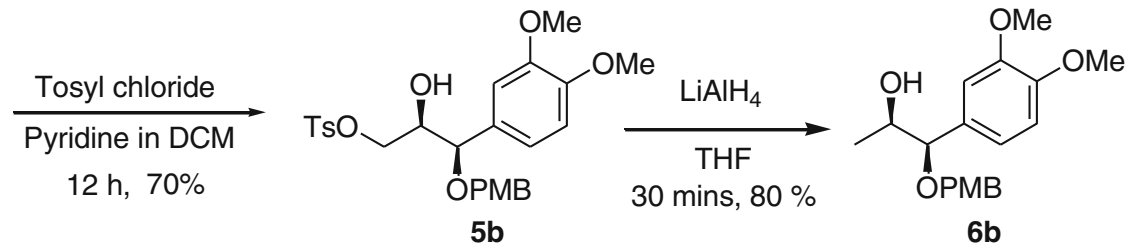

ref. $11 \mathrm{~b}, 11 \mathrm{~d}$<smiles>C/C=C/c1ccc(OC(C)C(O)c2ccc(OC)c(OC)c2)c(OC)c1</smiles>

7b, Virolin (threo isomer)<smiles>CC(O)C(O)c1ccc(O)cc1</smiles>

$8 b$

Scheme 3. Formal synthesis of virolin. 


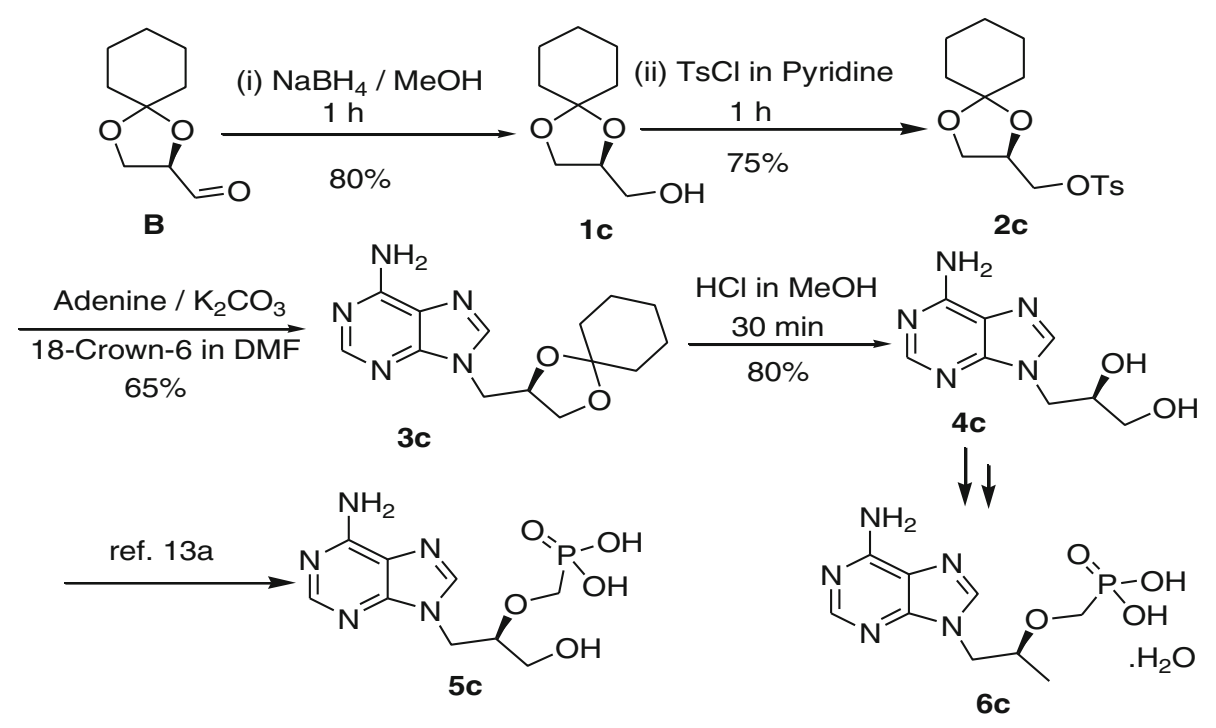

Scheme 4. Formal synthesis of HPMPA.

synthesis of optically active acyclic nucleoside and nucleotide analogues. ${ }^{14}$ These compounds are used as antiviral drugs such as inhibitors of viral DNA polymerases. ${ }^{14 a}$ Thus, (R)-2,3-O-cyclohexylidine glyceraldehydes (B) was treated with $\mathrm{NaBH}_{4}$ in $\mathrm{MeOH}$ for $1 \mathrm{~h}$ to afford the alcohol 1c in excellent yield (scheme 4). The primary alcohol $\mathbf{1 c}$ was then tosylated with $\mathrm{TsCl}$ in pyridine to get $\mathbf{2 c}$ in $75 \%$ yield. Now, the tosylate group in $\mathbf{2 c}$ was substituted by adenine in the presence of $\mathrm{K}_{2} \mathrm{CO}_{3}$ and 18-Crown-6 in $\mathrm{DMF}^{15}$ at $80^{\circ} \mathrm{C}$ to furnish $3 \mathbf{c}$ in $65 \%$ yield. Structure of $\mathbf{3 c}$ was confirmed by X-ray crystallographic study (figure 2).

Compound 3c was treated with $\mathrm{HCl}$ in $\mathrm{MeOH}$ to get the highly polar diol $\mathbf{4 c}$ in $80 \%$ yield as a crystalline solid. Since, compound $\mathbf{4 c}$ has already been converted $^{14 a}$ to the 3-hydroxy-2phosphonylmethoxypropyl adenine (HPMPA) (5c), an anti-pox agent, we may claim the formal synthesis of HPMPA. Our strategy for the synthesis of 9-(2,3dihydroxypropyl) adenine (DHPA) (4c) is found to be much superior compared to the reported procedure by Zakirova et al from D-ribose. ${ }^{14 a}$ Although

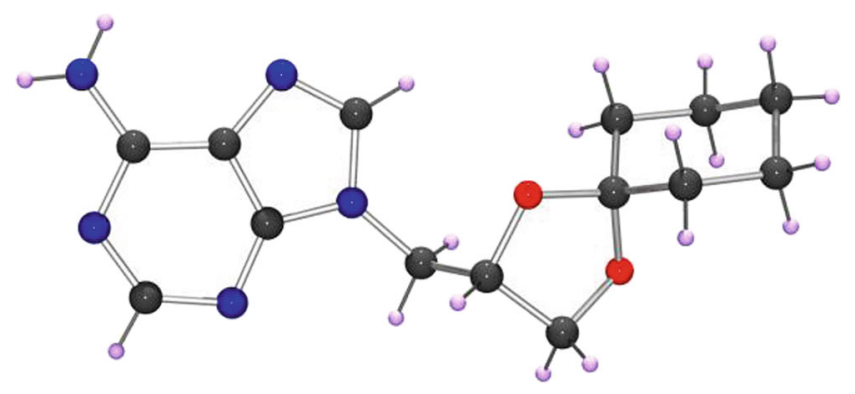

Figure 2. ORTEP diagram of compound 3c.
Holý et al. ${ }^{16}$ followed the similar strategy, our strategy is better with respect to the reaction time, purification procedure and yield of the products. Following the present method, few grams of pure $\mathbf{4 c}$ could easily be prepared within a day or so. We believe that the compound $\mathbf{4 c}$ could be an advanced intermediate for the synthesis of tenofovir (6c), an anti-HIV drug.

\section{Conclusion}

In conclusion, we have designed a generalized strategy for the synthesis of some advanced optically active intermediates which have broad spectrum of application in the synthesis of a variety of biologically active molecules involving simple chemistry and easily accessible starting materials without using any expensive chiral catalyst. These features of the strategy are expected to contribute sufficiently to scientific literature and arrogate industrial applications.

\section{Acknowledgements}

We sincerely thank the Department of Science and Technology (DST), New Delhi for financial support. SS thanks the council of Scientific and Industrial Research (CSIR), New Delhi, for awarding the fellowship. We express our sincere thanks to S Ray and N Chakraborty, Summer Project Fellows, for their help in preparing some of the starting materials. We also express our sincere thanks to Dr. S Paira, Inorganic Chemistry Department of this Institute for analysing X-Ray data. 


\section{References}

1. (a) Ludlow B S, Villo P, Häcker C and Somafi P 2010 Org. Lett. 12, 5274; (b) Liu Z, Shultz S, Sherwood C A, Krska S, Dormer P G, Desmond R, Lee C, Sherer E C, Shpungin J, Cuff J and Xu F 2011 Tetrahedron Lett. 52 1685; (c) Katsumura S, Yamamoto N, Morita H and Han Q 1994 Tetrahedron: Asymmetry 5 164; (d) Li P, Evans C D and Jullie M M 2005 Org. Lett. 7 5325

2. (a) Ma G, Bavadekar S A, Davis Y M, Lalchandani S G, Nagmani R, Schaneberg B T, Khan I A and Feller D R 2007 J. Pharmacol. Exp. Ther. 322 214; (b) Kim D J and Cho B T 2003 Bull. Korean Chem. Soc. 24 1641; (c) Shukla V B, Madyar V R, Khadilkar B M and Kulkarni P R 2002 J. Chem. Tech. BioTech. 77137

3. (a) Zhang L, Ding Z Y and Shi G Y 2009 Afr. J. Biotech. 8 694; (b) Schulze M 2010 Synth. Commun. 40 1416; (c) Page P C B, Buckley B R, Elsegood M R J, Hayman C M, Heaney H, Rassias G A, Taliba S A and Liddle J 2007 Tetrahedron 63 10991; (d) Ooka H, Arai N, Azuma K, Kurono N and Ohkuma T 2008 J. Org. Chem. 73 9084; (e) Buckley III T F and Rapoport H $1981 \mathrm{~J}$. Am. Chem. Soc. 1036157

4. Hanessian S 1986 Total synthesis of natural products: The 'chiron' approach, Prrgamon Press: Oxford, UK

5. Nishida A, Sorimachi H, Iwaida M, Matsumizu M, Kawate T and Nakagawa M 1998 Synlett 389

6. (a) Chikashita H, Nikaya T, Uemura $\mathrm{H}$ and Itoh $\mathrm{K}$ 1989 Bull. Chem. Soc. Jpn. 62 2121; (b) Mulzer J and Angermann A 1983 Tetrahedron Lett. 242843

7. (a) Malhotra R, Ghosh A, Ghosh R, Chakrabarti S, Dutta S, Dey T K, Roy S, Basu S and Hajra S 2011 Tetrahedron: Asymmetry 22 1522; (b) Arifa Husain A and
Ganem B 2002 Tetrahedron Lett. 43 8621; (c) Mengel A and Reiser O 1999 Chem. Rev. 991191

8. Castro A C, Depew K M, Grogan M J, Holson E B, Hopkins B T, Johannes C W, Keaney G F, Koney N O, Liu T, Mann D A, Nevalainen M, Peluso S, Perez L B, Snyder D A and Tibbitts T T 2008 PCT Int. Appl. WO2008024337 A2, 28 Feb

9. Effenberger F, Gutterer B and Jäger J 1997 Tetrahedron: Ayymmetry $\mathbf{8} 459$

10. Boruwa J, Borah J C, Gogoi S and Barua N C 2005 Tetrahedron Lett. 461743

11. Rao A V R, Gurjar M K, Lakshmipathi P, Reddy M M, Nagarajan M, Pal S, Sarma B V N B S and Tripathy N K 1997 Tetrahedron Lett. 387433

12. (a) Das S K, Das K S and Panda G 2010 Eur. J. Org. Chem. 5100; (b) Curti C, Zanardi F, Battistini L, Sartori A, Rassu G, Pinna L, Casiraghi G 2006 J. Org. Chem. 71 8552; (c) Yuan H J, Cheng Y Y, Qian S, Xiao X and Wu Y 2010 Chinese Chem.l Lett. 21 127; (d) Xia Y and Wang W 2010 Chemical Papers 64 630; (e) Lee A L, and Ley S V 2003 Org. Biomol. Chem. 1 3957; (f) Li Y, Cheng W, Zhu C, Yao C, Xiong L, Tian Y, Wang S, Lin S, Hu J, Yang Y, Guo Y, Yang Y, Li Y, Yuan Y, Chen N and Shi J 2011 J. Nat. Prod. 741444

13. Balboul B A A A, Ahmed A A, Otsuka H and Adams A D 1996 Phytochemistry 421191

14. (a) Zakirova N F, Shipitsyn A V, Belanov E F and Jasko M V 2004 Bioorg. Med. Chem. Lett. 14 3357; (b) Patching S G, Baldwin S A, Baldwin A D, Young J D, Gallagher M P, Henderson P J F and Herbert R B 2005 Org. Biomol. Chem. 3 462; (c) Hirota K, Monguchi Y, Sajiki H and Kitade Y 1997 Synlett 697

15. Rustullet A, Alibès R, March P D, Figueredo M and Font J 2007 Org. Lett. 92827

16. Holý A and Ivanova G S 1974 Nucleic Acid Res. 119 